\title{
Management Shareholding Incentives and Enterprise Environmental Investment-Evidence from A-Share Heavily Polluting Industry Listed Companies
}

\author{
Han Wu \\ School of Management, Jinan University, Guangzhou, China \\ Email: hannah950719@126.com
}

How to cite this paper: $\mathrm{Wu}, \mathrm{H}$. (2020) Management Shareholding Incentives and Enterprise Environmental InvestmentEvidence from A-Share Heavily Polluting Industry Listed Companies. Modern Economy, 11, 37-50.

https://doi.org/10.4236/me.2020.111005

Received: December 24, 2019

Accepted: January 6, 2020

Published: January 9, 2020

Copyright $\odot 2020$ by author(s) and Scientific Research Publishing Inc. This work is licensed under the Creative Commons Attribution International License (CC BY 4.0).

http://creativecommons.org/licenses/by/4.0/

\begin{abstract}
This paper adopts the sample of heavily polluting industry listed companies' data from 2013 to 2018, takes the amount of investment related to environmental protection in "projects under construction" divided by the capital stock as the proxy variable of environmental investment, takes the shareholding ratio of management as the proxy variable of shareholding incentive, empirically tests the relationship between the environmental investment and the incentive of stock ownership, and finds that the incentive of stock ownership significantly promotes the level of environmental investment. In addition, the incentive effect of stock ownership on the level of environmental investment only exists in the sample's fierce industry competition.
\end{abstract}

\section{Keywords}

Management Shareholding Incentives, Environmental Investment,

Principal-Agent Problem

\section{Introduction}

The reform and opening up has brought about China's rapid economic growth, but at the same time it has paid a heavy price of environment and resources. Environmental protection concerns the national economy and people's livelihood and is crucial to sustainable development, public awareness of environmental protection is also increasing, green development has become a hot topic.

However, from the perspective of the investment in environmental pollution control in China, the government is still the main body of environmental pollu- 
tion control in China, and the heavy polluting enterprises, which produce the most of China's environmental pollution, have not yet assumed the responsibility of the main body of environmental control. Until today, when environmental regulations are strengthened and public awareness of environmental protection is enhanced, most heavy polluting enterprises have not corrected their original concept and will not take the initiative to carry out environmental governance and environmental investment based on opportunism. Therefore, how to promote heavy polluting enterprises to increase environmental investment has become a topic of common concern in academia and practice circles.

Previous studies focused more on the relationship between environmental investment and environmental regulation or external governance mechanism, and less on internal governance mechanism. In this paper, we focus on the important influence of company executives in the operation and management of the company, including the company's environmental protection policies and implementation, investigating the driving force of promoting environmental investment from the perspective of executive shareholding incentive. Executives usually have a tenure system, and their earnings mainly come from the short-term compensation, which depends on their short-term operating performance. Therefore, in an information asymmetry environment, managers tend to choose to do the decisions that are beneficial to their own wealth but may be detrimental to the long-term development of enterprises. Investment in environmental protection is usually regarded as an investment that cannot bring economic benefits to the enterprise immediately while increasing the cost of the enterprise. The short-sightedness of executives makes them focus on short-term economic benefits and ignore the long-term environmental benefits. In the past studies, in order to overcome the principal-agent problem of executives' short-sightedness, the incentive measure of executives' shareholding was introduced, aiming at coordinating the interests between executives and shareholders. In theory, the mechanism that can motivate the management to pay attention to long-term development goals is inherently consistent with the behavior of enterprises' environmental investment, which conforms to the long-term interests of enterprises. However, whether the incentive of the management' stock ownership can effectively promote the environmental investment has not been systematically answered in empirical studies. Therefore, based on the principal-agent theory and the externality theory, this paper attempts to test the relationship between the two from an empirical perspective, hoping to further enrich the relevant literature on the driving factors of environmental investment, and to test the effectiveness of executive shareholding incentive to solve the principal-agent problem from the perspective of environmental investment.

\section{Theoretical Basis and Literature Review}

\subsection{Principal-Agent Problem}

Jensen and Mecking (1976) systematically explained the principal-agent rela- 
tionship, elaborated the concept of agency cost and proposed the principal-agent theory. Principal-agent theory is that, with the emergence of big development and large-scale development of productivity, social division of labor and specialization makes the owner entrust their wealth capital agents for decision-making and management, but the agents do not enjoy the residual claims, leading to the interest deviation between principal and agent.

Therefore, the central task of principal-agent theory is to study how to design the optimal contract to realize interest convergence under the circumstance of conflicting interests and asymmetric information. In business management, equity incentive for agents is usually regarded as the main means to solve the agency problem. If the option or stock is granted to the agents, the agents will also be granted the status of shareholder, so that the manager can enjoy part of the residual claim of the enterprise. This method can effectively bind the interests of the management and shareholders, share the interests and risks, and jointly maximize the wealth of shareholders.

\subsection{Externality Theory}

Pigou thought that externality refers to the phenomenon that the marginal private net value deviates from the marginal social net value. External economy (also known as positive externalities) refers to the positive external effects of a certain economic activity on the producer or consumer. External diseconomies (also known as negative externalities), on the other hand, refer to an economic activity that has a negative impact on the outside world, but at no cost to the party causing the negative impact.

Based on the characteristics of externalities mentioned above, Pigou believed that taxing negative externalities and subsidizing positive externalities could reduce the gap between marginal private net output and marginal social net output, which would result in an increase in economic welfare.

\subsection{The Economic Consequences of Management Ownership Incentives}

Scholars empirically explored the effectiveness of executive ownership incentive in solving principal-agent problems from different perspectives, including the level of risk taking of management, corporate performance, earnings management behavior and investment efficiency.

Compared with shareholders, the risks of the management are difficult to be dispersed, so the management is usually unwilling to take risks on their own, and the decisions they make are often not the optimal solution. In order to alleviate the conflict of interests between shareholders and the management and realize the convergence of their interests, it is a universal solution for the management to hold a part of the enterprise's equity. Coles et al. found that there was a causal relationship between management incentives and corporate investment and financing decisions and corporate risks [1]. The higher the sensitivity 
of CEO wealth to stock fluctuations, the higher the risk level of management is, it was reflected in more R\&D investment, less fixed asset investment and higher leverage ratio. Low (2009) found that when CEO wealth was more sensitive to stock returns, the company would adopt more risky policies, such as more aggressive financing policies [2].

In order to realize the maximization of enterprise value, shareholders often grant certain equity to the management. However, whether the incentive behavior can improve enterprise performance has not been determined yet. Some scholars support the positive effect of management shareholding incentives through empirical analysis. Ye and Chen (2008) found a significant positive correlation between the shareholding ratio of the management and enterprise value in high-tech industry [3]. Lin and Su (2011) took the ROA as a measure of corporate performance and found that equity incentive can help improve the ROA of non-state holding companies [4].

However, scholars have also noticed that the share grant itself is susceptible to the influence of management power, which may not only lead to the "welfare" of share grant, but even strengthen the "entrenchment effect". Executive ownership may induce agency problems and lead to higher agency costs. Therefore, scholars believe that the incentive to the management should have a proper degree and interval effect.

\subsection{Literature Research on Driving Factors of Environmental Investment}

From the perspective of driving factors research, the research can be divided into two perspectives: external factors and internal factors of enterprises. External factors mainly include environmental regulation, pressure of social public opinion and demands of stakeholders, while internal factors mainly include executive political connection and corporate governance structure.

Based on Porter's hypothesis, natural endowment hypothesis and pollution paradise hypothesis, scholars have conducted extensive research on environmental investment at macro and micro levels. Xie et al. (2014) found that the intensity of environmental regulation and environmental investment exist between stable and significant positive correlation, and bring the ascension on the productivity [5]. However, some scholars tend to support the factor endowment hypothesis. Li and Tian (2016) took listed companies in China's heavily polluting industries from 2008 to 2013 as sample and found an inverted u-shaped relationship between corporate environmental investment and environmental regulation. Some scholars support the pollution paradise hypothesis [6]. Broberg et al. (2013) showed a significant negative correlation between environmental regulation and corporate environmental investment, supporting the explanation of the pollution paradise hypothesis [7].

Some scholars have done the research about the driving factors of environmental investment from the perspective of corporate governance. Brio et al. 
(2007) demonstrated empirically that the realization of an enterprise's competitive advantage at the environmental level requires the deep involvement and strategic integration of the management, as well as the full display of employees' enthusiasm and participation [8]. Scholars have studied the impact of corporate governance on environmental investment from the perspectives of shareholders, directors and executives. Tang and Li (2013) concluded that equity balance degree, management shareholding respectively with the company's environmental investment scale was significantly negative relationship, big shareholders and the management general lack of environmental management and environmental investment's enthusiasm, and they appear to act in concert [9]. Other scholars believed that equity concentration was negatively correlated with environmental investment, and major shareholders lack environmental protection awareness and had not yet clearly understood the long-term value of environmental investment. Furthermore, Ni (2018) concluded that politically connected companies tend to have a better understanding of environmental intentions and decisions, and receive more attention and pressure from domestic stakeholders to promote green development [10]. And Wang et al. (2017) believed that media attention can increase the environmental investment, think the media attention to a certain extent, play the role of the corporate governance, and changes in environmental regulation jointly promote the enterprise environmental behavior, exert positive media attention to enterprise's environmental governance function, promote the information disclosure and public participation, and gradually strengthen environmental regulation level [11].

\section{Hypotheses Development}

\subsection{Research on the Influence Mechanism of Manager Stock Ownership Incentive on Environmental Investment}

With the great development of productivity and the organization of scale, specialization and social division of labor enabled the holders of capital to entrust their wealth to agents with professional knowledge for decision-making and management. Shareholders who invest capital aim to maximize their own wealth and achieve long-term benefits through sustainable development. As the agent, the management is on a fixed-term basis, and the compensation assessment is also short-term, which makes the senior management pay more attention to short-term interests. The conflict of interests between shareholders and the management leads to the improper decision-making behavior of the management, causing serious principal-agent problems.

The above principal-agent problem is also reflected in the decision-making of environmental investment. Stakeholder theory points out that enterprises' environmental governance behaviors meet the requirements of stakeholders, and the cumulative effect of environmental investment will significantly promote the long-term performance of enterprises. Therefore, environmental investment is closely related to the long-term interests of enterprises. From the perspective of 
shareholders, enterprises should actively invest in environmental protection. But environmental investment may cause costs rising, and reduce the profits in the short term, the short-sighted executives pursue the performance of his tenure, and out of opportunism, restrict the size of the environmental investment.

The principal-agent theory holds that when the interests of the shareholder and the management are inconsistent, shareholders can limit the abnormal behaviors of the management through incentives, constraints and supervision [12]. Long-term incentives for management will effectively reduce agency costs and weaken the opportunistic motivation, urging managers to strive for enterprise value. The influence of management shareholder incentive on environmental investment is mainly reflected as follows:

First, stock ownership incentive for the management can realize the convergence of the interests of the management and shareholders and enable the senior management team to claim the residual value of the enterprise. With shareholder identity, they both enjoy the right strategic choice for the company return, and to undertake strategic errors caused by the loss, so the strategy will be more cautious, they will incorporate more long-term interests into the decision-making, weaken the opportunism behavior, environmental investment attraction is much appealing, shares the enthusiasm of executives to make environmental investment is higher.

In conclusion, the managers who are encouraged by shareholding have more motivation to make environmental investment. Moreover, with the increase of shareholding ratio, the management' sense of belonging to the company increases and their development vision becomes more long-term, so as to further improve the level of environmental investment of the company. Therefore, hypothesis 1 is proposed as follows:

Hypothesis 1: there is a significant positive correlation between corporate environmental investment and executive shareholding incentives.

\subsection{The Influence of Industry Competition on the Relationship between the Management Shareholding Incentives and Environmental Investment}

The industry environment plays an important role in determining the strategic decisions of enterprises, the investment decisions and behaviors of enterprises will inevitably be affected by the industry environment and industry characteristics. According to the theory of super property right, it is necessary to cooperate with the external competition environment for the internal governance mechanism of enterprises to play a better role. Tan Yunqing et al. (2008) found that there was a significant complementary relationship between the level of product market competition and manager motivation [13]. The higher the level of product market competition, the higher the level of enterprise motivation and the higher the level of managers' efforts. Shen et al. (2012) believed that in China, the important institutional basis for the effectiveness of equity incentive is an effective 
market competition environment [14]. It can be seen that the product market competition, an external governance factor, may play a moderating role in the relationship between the incentive of the management' stock ownership and enterprises' environmental investment.

In industries with high degree of product market competition, enterprises face greater bankruptcy pressure and serious product homogeneity. If heavily polluting industries make environmental investment to achieve product differentiation and win the recognition of consumers, they can achieve higher profits. The above changes caused by the product market competition mechanism have changed the expected net present value of environmental investment and increased the attraction of environmental investment. The external competitive pressure makes executives feel the benefits of environmental investment more easily and change their investment intention. In conclusion, hypothesis 2 is proposed as follows:

Hypothesis 3: product market competition can enhance the positive impact of management shareholding incentives on environmental investment.

\section{Empirical Research Design}

\subsection{Sample Selection and Data Sources}

This paper selects data from 2013 to 2018 of A share heavily pollution industry as the research sample. The sample is processed as follows: 1) the sample companies of ${ }^{*}$ ST and ST are excluded; 2) the sample data missing from the index data of some variables are excluded; after the above screening, the samples contained a total of 1430 observed values. Further, the primary variables are winsorize treated in the $1 \%$ and $99 \%$ subfractions to reduce the impact of extreme values. All data are from the CSMAR database.

\subsection{Variable Definition}

\subsubsection{Explained Variable}

The explained variable in this paper is the environmental investment (EPI) of enterprises. According to the practice of Ji and $\mathrm{Su}$ (2016), the relative number of "investment/capital stock" is adopted to measure environmental investment [15], which can eliminate or reduce the impact of enterprise scale on environmental investment scale, thus making the environmental investment data of each enterprise have certain comparability. Since China's environmental investment level is generally low, in order to make the regression results easier to observe, this paper takes the value of investment/capital stock multiplied by 100 as the explained variable for regression.

\subsubsection{Explaining Variable}

The explanatory variable was the management shareholder incentives (manage). Referring to the measurement method of stock ownership incentive proposed by Sheng et al. (2016) [14], this paper uses the number of shares held by the management divided by the total share capital of the company to measure the incen- 
tive intensity of stock ownership by the management.

\subsubsection{Moderating Variable}

Industry competition. In order to maintain the comparability with previous studies, this paper uses the method of Liu and Li (2013) for reference, and uses the Herfindal-Hirschmann index (HHI) for measurement [16]. Firstly, it calculates the revenue share of each company in each industry, and then sums the square of the market share of each company in the industry. For the convenience of narration, this index is multiplied by $(-1)$, which is designated as the variable measurement indicator HHI. The larger the HHI, the more dispersed the market forces, the more intense the industry competition.

$$
\mathrm{HHI}=\sum_{i=1}^{N}\left[X_{i} / X\right]^{2} *(-1)
$$

where, HHI stands for Herfindahl index;

$X i$ represents the main business income of enterprise $i$;

$X$ represents the total main business income of the market in the industry;

$N$ stands for the number of enterprises in the industry.

\subsubsection{Control Variables}

This paper refers to Ji and $\mathrm{Su}$ (2016) to design the control variables [17]. The control variables include the three indicators of enterprise characteristics and financial performance, external environment and corporate governance, as shown in Table 1.

Table 1. Variable definition.

\begin{tabular}{ll}
\hline Variables & Variables Definition \\
\hline EPI & Environmental investment divided by total investment \\
Manage & Shares held by the management divided by the total share capital of the company \\
SOE & Property right, set equal to 1 if state-owned, otherwise it is 0 \\
HHI & Herfindal-Hirschmann index to calculate the degree of industry competition \\
Cost & The ratio of management fee, to calculate the agent cost \\
ROA & Net profit divided by total asset \\
Growth & The growth in income \\
Cashflow & Net operating cash flow divided by total assets \\
Levi & Financial leverage \\
Size & The logarithm of total assets \\
Age & The number from the company lists \\
Reg & Environmental regulation \\
First & The share hold by the first shareholder divided by total share \\
Director & The size of the board \\
Indep & The number of independent directors by the total number of the board director \\
Bage & The average age of the board
\end{tabular}




\subsection{Empirical Model}

In order to verify the impact of management shareholding incentive on enterprise environmental investment, according to the design of explained variables, explanatory variables and control variables above, we refer to Ji and Su (2016) and construct the model, the model in this paper is as follows [17]:

$$
\text { EPI }=\alpha+\beta_{1} \text { Manage }+\sum \text { Controls }+\sum \text { Industries }+\sum \text { Year }+\varepsilon
$$

\section{Empirical Results}

\subsection{Descriptive Statistics}

As can be seen from Table 2, the overall level of environmental investment (EPI) is relatively low, the median is lower than the mean, indicating that the environmental investment of the most enterprises are lower than the mean. The difference between the maximum value and the minimum value is large, indicating that the environmental investment level of different enterprises is quite different. The mean management shareholding ratio (Manage) is only 0.0556 , with a median of 0 , indicating that the management shareholding ratio in heavily polluted industries is not very high. The maximum value of assets and liabilities ratio (Levi) is 0.955 , and the minimum value is 0.0447 . There is little difference between mean and median, and the distribution is relatively uniform. Environmental regulation variable (Reg) indicates that the proportion of pollution source governance in GDP is still low, the level of environmental governance varies greatly among regions, and the intensity of environmental regulation varies. The shareholding ratio of the largest shareholder in the heavily polluted industry is $77.07 \%$ at the highest and $9.086 \%$ at the minimum. The shareholding structure of the listed companies in the heavily polluted industry varies greatly. As can be seen from the property right nature (SOE) indicator, among the enterprises investing in environmental protection, state-owned enterprises account for 51.9\%, and there is no significant difference in the number of state-owned enterprises and non-state-owned enterprises. The average age of management is 40.91 years old at the minimum and 58.4 years old at the maximum, and the age of management varies greatly among enterprises. There is great heterogeneity among enterprises, which leads to great differences in investment decisions.

\subsection{Regression Results}

Table 3 shows the full sample regression results of management shareholding incentive and environmental investment. The regression coefficient of executive shareholding incentive is 0.48 , which is significantly positive at the level of $5 \%$.

This shows that after controlling for the influence of other factors, there is a significant positive correlation between the incentive of the management' shareholding and the enterprise's environmental investment. The higher the incentive intensity of the management' shareholding, the higher the level of enterprise's environmental investment. The conclusion supports hypothesis 1. 
The empirical results prove that equity incentive for the management can promote the long-term vision of the future development of the management, so that they are more likely to carry out environmental protection behaviors and invest more funds in environmental protection.

In terms of other variables, the enterprise profitability (ROA) is significantly positive, regression coefficient is 0.99 , shows that the higher the earnings level, the higher the investment level of environmental protection will be, possible explanation is that after the enterprise reaches considerable profit level, they are more likely to fulfill corporate social responsibility.

Ning and Li (2012) believe that external governance mechanism can influence the effect of internal governance mechanism, which is also verified in the conclusion of this paper [18]. It can be seen from Table 4 that the degree of competition in the product market is significantly positively correlated with the enterprise's environmental investment, indicating that the more intense the market competition is, the more likely the enterprise is to try to gain competitiveness through environmental investment. At the same time, industry competition, an external governance mechanism, also plays a regulating role in the relationship between the management shareholding incentives and environmental investment. Table 4 shows that the cross product term is significantly positive, indicating that the more competitive the industry is, the more positive influence the management shareholding incentives has on the environmental investment.

Table 2. Descriptive statistics.

\begin{tabular}{ccccccc}
\hline Variables & $\mathrm{N}$ & Mean & Median & SD & Min & Max \\
\hline EPI & 1430 & 0.62 & 0.23 & 0.95 & 0.01 & 3.99 \\
Manage & 1430 & 0.0556 & 0 & 0.129 & 0 & 0.652 \\
ROA & 1430 & 0.063 & 0.0542 & 0.082 & -0.154 & 0.278 \\
Growth & 1430 & 0.149 & 0.0825 & 0.367 & -0.472 & 2.486 \\
Age & 1430 & 17.75 & 18 & 4.976 & 6 & 30 \\
Levi & 1430 & 0.468 & 0.475 & 0.216 & 0.0447 & 0.955 \\
Cashflow & 1430 & 0.0639 & 0.061 & 0.0703 & -0.134 & 0.243 \\
Reg & 1430 & 0.0012 & 0.0009 & 0.0009 & 0.0001 & 0.0099 \\
SOE & 1430 & 0.519 & 1 & 0.5 & 0 & 1 \\
First & 1430 & 37.35 & 36 & 15.11 & 9.086 & 77.07 \\
Director & 1430 & 8.916 & 9 & 1.699 & 4 & 17 \\
Indep & 1430 & 0.371 & 0.333 & 0.0557 & 0.182 & 0.667 \\
Bage & 1430 & 50.13 & 50.12 & 2.709 & 40.91 & 58.4 \\
\hline
\end{tabular}


Table 3. Regression results of the management shareholding incentives and environmental investment.

\begin{tabular}{|c|c|}
\hline VARIABLES & EPI \\
\hline \multirow[t]{2}{*}{ Manage } & $0.48^{* *}$ \\
\hline & $(0.042)$ \\
\hline \multirow[t]{2}{*}{ ROA } & $0.99^{* *}$ \\
\hline & $(0.019)$ \\
\hline \multirow[t]{2}{*}{ Growth } & -0.04 \\
\hline & $(0.535)$ \\
\hline \multirow[t]{2}{*}{ Age } & -0.01 \\
\hline & $(0.236)$ \\
\hline \multirow[t]{2}{*}{ Levi } & $0.26^{*}$ \\
\hline & $(0.092)$ \\
\hline \multirow[t]{2}{*}{ Cashflow } & -0.02 \\
\hline & $(0.968)$ \\
\hline \multirow[t]{2}{*}{$\operatorname{Reg}$} & $0.12^{* *}$ \\
\hline & $(0.022)$ \\
\hline \multirow[t]{2}{*}{ SOE } & $-0.11^{*}$ \\
\hline & $(0.064)$ \\
\hline \multirow[t]{2}{*}{ First } & $0.01^{*}$ \\
\hline & $(0.096)$ \\
\hline \multirow[t]{2}{*}{ Director } & 0.00 \\
\hline & $(0.771)$ \\
\hline \multirow[t]{2}{*}{ Indep } & $-1.41^{* * *}$ \\
\hline & $(0.000)$ \\
\hline \multirow[t]{2}{*}{ Bage } & -0.02 \\
\hline & $(0.186)$ \\
\hline \multirow[t]{2}{*}{ Constant } & $1.45^{\star *}$ \\
\hline & $(0.039)$ \\
\hline Industry & Controlled \\
\hline year & Controlled \\
\hline Observations & 1,430 \\
\hline R-squared & 0.094 \\
\hline
\end{tabular}

Note: Numbers in parentheses are $\mathrm{p}$-values, ${ }^{* *}$ indicates $\mathrm{p}<0.01,{ }^{* *}$ indicates $\mathrm{p}<0.05$; ${ }^{*}$ indicates $\mathrm{p}<0.1$. 
Table 4. The influence of industry competition on the relationship between the managements shareholding incentives and environmental investment.

\begin{tabular}{|c|c|}
\hline VARIABLES & EPI \\
\hline \multirow[t]{2}{*}{ Manage } & $1.01^{* *}$ \\
\hline & $(0.020)$ \\
\hline \multirow[t]{2}{*}{ HHI } & $1.14^{* *}$ \\
\hline & $(0.031)$ \\
\hline \multirow[t]{2}{*}{ Manage ${ }^{\star} \mathrm{HHI}$} & $8.56^{*}$ \\
\hline & $(0.072)$ \\
\hline \multirow[t]{2}{*}{ ROA } & $0.79^{*}$ \\
\hline & $(0.066)$ \\
\hline \multirow[t]{2}{*}{ Growth } & -0.01 \\
\hline & $(0.819)$ \\
\hline \multirow[t]{2}{*}{ Age } & -0.01 \\
\hline & $(0.261)$ \\
\hline \multirow[t]{2}{*}{ Levi } & $0.39^{* * *}$ \\
\hline & $(0.008)$ \\
\hline \multirow[t]{2}{*}{ Cashflow } & 0.03 \\
\hline & $(0.955)$ \\
\hline \multirow[t]{2}{*}{ Reg } & -0.07 \\
\hline & $(0.365)$ \\
\hline \multirow[t]{2}{*}{ SOE } & 0.02 \\
\hline & $(0.764)$ \\
\hline \multirow[t]{2}{*}{ First } & 0.01 \\
\hline & $(0.125)$ \\
\hline \multirow[t]{2}{*}{ Director } & 0.01 \\
\hline & $(0.529)$ \\
\hline \multirow[t]{2}{*}{ Indep } & $-1.62^{* * *}$ \\
\hline & $(0.000)$ \\
\hline \multirow[t]{2}{*}{ Bage } & -0.01 \\
\hline & $(0.354)$ \\
\hline \multirow[t]{2}{*}{ Constant } & $1.47^{\star *}$ \\
\hline & $(0.021)$ \\
\hline Area & Controlled \\
\hline year & Controlled \\
\hline Observations & 1430 \\
\hline R-squared & 0.106 \\
\hline
\end{tabular}




\section{Conclusions}

With the strengthening of environmental regulation in China and the increasing awareness of environmental protection among citizens, enterprises, as the main polluters, should further improve their investment in environmental protection. In view of this, this paper attempts to explore whether the internal governance mechanism of management shareholding incentive can promote enterprises to make environmental investment from the perspective of the management, from the empirical level. This article bases on the 2013-2018 data of A-share listed companies of heavily pollution industry as the research sample, takes the environmental-related investment divided by capital stock as proxy variable of environmental investment, management shareholding ratio as the proxy variable of management shareholding incentive, empirically studies the relationship between management shareholding incentive and the environmental investment, finds that management shareholding motivation significantly promoted the enterprise investment level of environmental protection. It shows that the incentive of the management stock ownership promotes the consideration of long-term interests of the management and realizes the convergence of interests of the management and shareholders. This paper explains the role of the incentive of the management stock ownership in solving the principal-agent problem from the perspective of environmental investment.

In addition, this paper examines the difference in the level of environmental investment promoted by the incentive of manager stock ownership under different intensity of industry competition. The results show that the incentive effect of stock ownership on the level of environmental investment only exists in the sample's fierce industry competition. The research in this paper enriches the research on driving factors of environmental investment and explains the effectiveness of stock ownership incentive for the management in alleviating principal-agent problem from the perspective of environmental investment.

\section{Conflicts of Interest}

The author declares no conflicts of interest regarding the publication of this paper.

\section{References}

[1] Coles, J.L., Daniel, N.D. and Naveen, L. (2005) Managerial Incentives and Risk-Taking. Journal of Financial Economics, 79, 431-468. https://doi.org/10.1016/j.jfineco.2004.09.004

[2] Low, A. (2009) Managerial Risk-Taking Behavior and Equity-Based Compensation. Journal of Financial Economics, 92, 470-490. https://doi.org/10.1016/j.jfineco.2008.05.004

[3] Ye, J.F. and Chen, X. (2008) Research on the Influence of Senior Management Shareholding on Enterprise Value in China-Evidence from Hi-Tech Industry Listed Companies. Research on Financial and Economic Issues, No. 3, 101-108.

[4] Lin, D.P. and Su, D.W. (2011) CEO Stock Incentives and Firm Performance-Based 
on the Earnings Management. Journal of Financial Research, No. 9, 162-177.

[5] Jie, M.H., Wang, J. and Liu, D.M. (2014) Environment Regulation, Technological Innovation and Corporate Performance. Nankai Business Review, 17, 106-113.

[6] Li, Q. and Tian, S.S. (2016) Can Environmental Regulation Promote Corporate Environmental Investment-Considering the Influence of Market Competition. Journal of Beijing Institute of Technology (Social Sciences Edition), 18, 1-8.

[7] Broberg, T., Samakovlis, E., Hammar, H. and Marklund, P.O. (2013) Testing the Porter Hypothesis: The Effects of Environmental Investments on Efficiency in Swedish Industry. Journal of Productivity Analysis, 40, 43-56. https://doi.org/10.1007/s11123-012-0335-6

[8] Brio, J.A.D., Fernandez, E. and Junquera, B. (2007) Management and Employee Involvement in Achieving an Environmental Action-Based Competitive Advantage: An Empirical Study. The International Journal of Human Resource Management, 18, 491-522. https://doi.org/10.1080/09585190601178687

[9] Tang, G.P. and Li, L.H. (2013) Equity Structure, Property Right Nature and Enterprise Environmental Protection Investment. Research on Financial and Economic Issues, No. 3, 93-100.

[10] Wang, Y., Li, Y.X., Ma, Z. and Song, J.B. (2017) Media Attention, Environmental Regulation and Enterprise Investment in Environmental Protection. Nankai Business Review, 20, 83-94.

[11] Ni, J. (2018) Research on the Influence of Political Connection on Environmental Protection Investment of Private Enterprises. Zhongnan University of Economics and Law, Wuhan.

[12] Jensen, M.C. and Mecking, W.H. (1976) Theory of the Firm: Managerial Behavior, Agency Costs and Ownership Structure. Journal of Financial Economics, 3, 305-360. https://doi.org/10.1016/0304-405X(76)90026-X

[13] Davidson, C.E. (2005) Taking Industry Seriously in Information Systems Research. MIS Quarterly, 29, 591-605. https://doi.org/10.2307/25148701

[14] Shen, H.B., Xie, Y. and Chen, Z.R. (2012) Environmental Protection, Corporate Social Responsibility and Its Market Response-Case Study Based on the Environmental Pollution Incident of Zijin Mining Group Co. China Industrial Economics, No. 1, 141-151.

[15] Ji, S. and Su, M. (2016) The Motivation of the Environmental Costs Internalization: Is It for Policy Compliance or for Profits? - Empirical Evidence from Chinese Listed Companies in Heavy Polluting Industries. Accounting Research, No. 11, 69-75.

[16] Sheng, M.Q. Zhang, C.Q. and Wang, Y. (2016) Managerial Equity Incentive and Capital Structure Dynamic Adjustment. Accounting Research, No. 2, 44-50+95.

[17] Liu, F.W. and Li, Q. (2013) Market Competition, EVA Evaluation and Corporate Over-investment. Accounting Research, No. 2, 54-62+95.

[18] Ning, J.Y. and Li, J. (2012) Product Market Competition, Corporation Governance and the Accounting Information Disclosure. Contemporary Economy \& Management, 34, 26-30. 